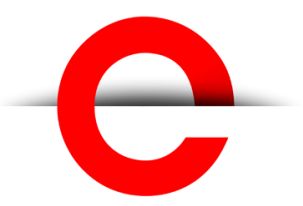

U T S

e PRES S
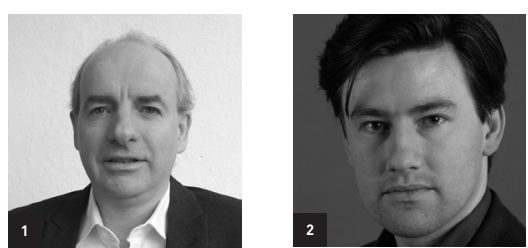

Project Management

Research and

Practice

Vol. 3

July-Dec. 2016

GUEST EDITORIAL

\title{
Reinvigorating project management research and practice: perspectives from the nonprofit sector
}

\author{
John Lannon', John N. Walsh ${ }^{2}$ \\ Kemmy Business School, University of Limerick, Limerick, V94 T9PX, Ireland \\ Corresponding author: John Lannon, Kemmy Business School, University of Limerick, \\ Limerick, V94 T9PX, Ireland. John.Lannondul.ie
}

DOI: http://dx.doi.org/10.5130/pmrp.v3i0.5119

(c) 2016 by the author(s). This is an Open Access article distributed under the terms of the Creative Commons Attribution 4.0 International (CC BY 4.0) License (https:// creativecommons.org/ licenses/by/4.0/), allowing third parties to copy and redistribute the material in any medium or format and to remix, transform, and build upon the material for any purpose, even commercially, provided the original work is properly cited and states its license.

Citation: Lannon, J. \& Walsh, J.N. 2016. Reinvigorating project management research and practice: perspectives from the nonprofit sector. Project Management Research and Practice, 3, 5119. http://dx.doi. org/10.5130/pmrp.v3i0.5119

Published by UTS ePRESS | http://pmrp.epress.lib.uts. edu.au
The genesis of this Special Issue was the conference Delivering Social Good: Managing Projects in the Non-Profit Sector held at the University of Limerick, Ireland, in October 2014. The diversity that exists within the broad nonprofit sector became apparent at this event, as did its increasing projectification, and the variety of organizational forms and models resulting from this trend. Tools, techniques, processes, and practices inherited from the business world were described, as were methodologies adopted, adapted, and specifically designed for work in areas like international development, humanitarian assistance, and community settings. Insights into the lived experiences of project managers in the nonprofit sector were also shared, as were a number of diverse conceptualizations of temporary organizations.

Inevitably, one of the themes of the conference was use of approaches developed in, and for, the business community. Much work has been done on the transfer of organizational and managerial concepts from business to the nonprofit world (Beck et al. 2008; Tucker \& Parker 2013), and there is evidence that many nonprofit organizations (NPOs) are becoming more "businesslike" (Maier et al. 2016). But, as Peter Drucker said in his book Managing the non-profit organization: practices and principles, the NPO exists to bring about a change in individuals or society, and the task of an NPO manager is to convert this into specifics (Drucker 2004). The adoption of business-oriented approaches and tools is seen as a means to improve performance in NPOs (Carlos Pinho et al. 2014), but consideration also needs to be given to the context in which they are being adopted, and to the sector's interests and primary aims (Myers \& Sacks 2003). 
From the perspective of project management research and practice, one such problem is that nonprofit work is not always an economic and techno-scientific concern, but a "moral-ethical concern” (Cicmil \& O'Laocha 2016, p. 547), particularly when it signifies the idea(1)s of social good and social action. The inclination toward "managerialist, technocratic, and instrumental" approaches (Ika \& Hodgson 2014) presents dilemmas relating to the understanding of issues like success and failure, accountability, risk sharing, and agency (Cicmil \& O'Laocha 2014). At a practical level, it can introduce overheads that are seen as wasteful of limited resources, or it can create tensions in collaborative spaces where organizations that are working together to affect social change adopt different approaches. Nonetheless, in areas like international development such approaches are becoming the norm.

Most international assistance provided to developing countries is project-based (Diallo \& Thuillier 2005; Ika et al. 2010), with a progressive adoption of a wide range of project management tools now evident (Golini et al.2015). As in other parts of the nonprofit world, the need to demonstrate effective results and to share the same spaces as for-profit actors, both as collaborators and competitors (Ryan 2002), has resulted in a more functionalist approach to management. This has led to an instrumental rationality that favours "theory for practice" over "theory of practice" (Cicmil et al. 2006). While this is an important aspect of the management of projects, attention also needs to be given to the operation of power in any social setting, and to the multiplicity of perspectives that prevail in most nonprofit contexts. The practice of project management must also recognize the effect of the project on people, communities, organizations, the environment, power relations, and, in the case of projects that seek to bring about social change, on issues like equality, freedom, and prosperity (Helgadóttir 2008).

In general, there are not many studies of the nonprofit sector within the project management literature. Of the little research that has been undertaken, most is in the area of international development (Diallo \& Thuillier 2005; Khang \& Moe 2008; Ika et al. 2010; Ika 2012; Golini \& Landoni 2014; Ika \& Hodgson 2014; Golini et al. 2015; Lannon et al. 2016). These projects share characteristics with conventional projects in that they deliver goods and services; they are limited, temporary, unique, and multidisciplinary; and they face time, cost, and quality constraints (Lannon et al. 2016). But they also have a number of distinct characteristics. One is the lack of a defined and/or powerful customer, which means that project management needs to be proactive to beneficiary needs rather than being reactive. It also needs to be sufficiently flexible to be able to respond to project changes, while not losing sight of long-term goals. Another characteristic of international development projects is the number and diversity of stakeholders typically involved. This requires the use of approaches that are inclusive of a wide range of divergent actors, and of tools that are conducive to involving and informing all stakeholders. Another peculiarity relates to the environment itself, which is often difficult, complex, and risky for a variety of social, economic, and political reasons. To cope with this, the tools used must foster a systemic analysis of the context (Golini \& Landoni 2014) and must help with the management of a wide variety of risks.

Because resources are scarce, efficient planning becomes paramount on international development projects, as does the avoidance of waste, and the favouring of transparency and accountability. Traditional project management techniques that are best suited to projects with defined and quantified objectives, rather than longer-term social objectives, may not always be best suited to the needs of the communities intended to benefit from the project. According to Curtis \& Poon (2009), methods based on "certainty, predictability, and linearity" are often used because they help management, and not because they are efficient in achieving 
U T S

e P R E S S development outcomes. Having said that, non-governmental organizations (NGOs) that are heading up international development projects tend to prefer simple techniques to structured and analytical methodologies (Falgari et al. 2013), with project managers adopting tools progressively according to their experience and the organization for which they work.

A number of methodologies have been designed and developed to meet the specific needs of the international development sector in particular. These include the logical framework (LogFrame), PMDPro (developed by PM4NGO, an organization devoted to training and disseminating project management knowledge among NGOs), and PM4DEV (designed specifically for development organizations) (Golini et al. 2015; Keleckaite \& Meiliene 2015). Another part of the broad nonprofit world in which project management practices are widely adopted is humanitarian assistance: everything from short-term health care delivery to large-scale engineering benefits from project management practices. Whether or not these are conducive to proper participation from local actors is questionable (Krause 2014), but it is nonetheless the case that the logic of project management and its implication for bounding rationality is rarely challenged in the sector.

\section{Researching projects and project management within an organizational context}

In considering how the impact of technocratic project management approaches on organizations might fruitfully be explored, it is instructive to examine the development of perceptions on the role of information technology and information systems on organizations. Like the early project management research, early approaches to information systems research tended to be objectivist, assigning technology the role of an independent variable (Orlikowski \& Robey 1991) and relying on research to identify the impacts (Kling 1987). The overarching positivist perspective that existed in the information systems domain was unnecessarily restrictive, however, and resulted in a failure to recognize other research traditions. This placed restrictions on what and how phenomena were studied (Orlikowski \& Baroudi 1991).

Project management research faces a similar challenge, as reliance on a functionalist, instrumental view of projects diminishes - potentially marginalizing the role of project managers, and indeed all project participants, as social and political actors - because it is based on an assumption of "rationality, universality, objectivity, and value-free decisionmaking" (Cicmil \& Hodgson 2006), and the possibility of generalizing law-like predictions in knowledge. Indeed, Cicmil \& Hodgson (2006) argue that the extant project management literature is reliant on "the language of design, regularity, and control to propose models and prescriptions as a route to increasing the ability of humans to control complex worlds," and that this is done to the exclusion of alternative ways of reasoning. In a similar vein, Hodgson \& Cicmil (2007) talk about standards as creating and reifying objects, and the "marginalization of more reflexive forms of rationality and the suppression of autonomy." This is reminiscent of early information systems research on the role of technology in reinforcing established forms of organizing, in supporting the intensification and fusion of existing control mechanisms, and in being capable of supporting integrated and flexible operations while enabling a "disciplinary matrix of knowledge and power" (Orlikowski 1991).

An interesting aspect of the management literature in relation to technology has been that of absence/presence (Orlikowski 2010). In the economic analyses of technological innovation there is little or no discussion of technology (Pinch \& Bijker 1984), with artefacts either 
U T S

e PRES S absent, black-boxed, abstracted, or reduced (Orlikowki \& Iacono 2001). Following on from the management research of the 1950s and 1960s, which saw technology as an exogenous force (Woodward 1958; Harvey 1968), proponents of contingency theory in the 1960s and 1970s continued to take a positivist view. In the context of such a dominant paradigm, it was important for researchers to avoid creating an orthodoxy that precluded other perspectives. Orlikowski \& Baroudi (1991) identified three areas of concern in relation to widening the information systems research domain to include other perspectives. The first was ontological beliefs, and whether physical and social worlds are objective of humans or alternatively only exist through human action. The second was human rationality, or the intentionality associated with human action; and the third was social relations. Here the key question being the extent to which they are intrinsically stable and ordered, or essentially dynamic and conflicting. All of these concerns bear scrutiny in the context of project management research and its relevance to practice.

Over time, the information systems field saw the emergence of a social-action perspective, in which mechanistic notions of cause and effect were considered less useful, as social situations were not viewed as governed by knowable causal relationships (Hirschheim 1985). An emergent process perspective on technology was also evident. In this, ontological priority is given to human agency so that technology is seen as neither fixed nor neutral. Instead, meanings and uses are shaped by the actions and interests of various social groups (Barley 1986; Markus \& Robey 1988; Zuboff 1988; Kling 1991; Ciborra \& Lengel 1994). Influenced by the socio-technical school (Bijker, Hughes \& Pinch 1987; Bijker \& Laws 1992), as well as structuration theory (Giddens 1984), technology was initially viewed as embodying inscribed and stabilized structures, but was later seen as embodying structures that are open to change at the start before becoming stabilized for use (Orlikowski 2000). In arguing for a "practice lens," Orlikowski (2000) called for a change in perspective: rather than seeing knowledge as stable, she reconceptualizes it as "knowing in practice." This necessitates a change from seeing technologies as embodying structures to seeing structures as emergent and dependent on the reflexivity of knowledgeable human actors.

Both information systems and project management have the ability to legitimize certain ways of working, with the ability to outline in detailed operational terms the procedures to accomplish tasks. While providing efficient processes and methodologies to complete complex tasks, the structural properties provided by both have the ability to constrain individual actions and agency. It is possible for the project management discipline to develop ever more precise and complex methodologies for more turbulent environments, or more adaptations for diverse economic sectors. To take such a trajectory would provide useful and worthy outcomes, but would ignore some wider questioning in the role and nature of project management. We therefore encourage project management researchers, practitioners, and trainers to expand the range and richness of future understandings by importing concepts and theories from other disciplines (including but not restricted to information systems), and by exploring project management's use in nontraditional sectors (such as the nonprofit sector).

Insights provided by developments in the organization studies literature, into the situated and cultural nature of organizing, are also valuable. One way in which the field developed was in response the criticism that it had overlooked materiality (Orlikowski 2007), either through a techno-centric perspective, producing functional technologically deterministic claims (Barley 1988; Kling 1991; Suchman 1994) or through a human-centred perspective that has resulted, according to Button (1993) and Berg (1997), in the technology vanishing as a result of preoccupation with the social. Consequently, alternative conceptualizations that 
U T S

e P R E S S challenged conventional distinctions emerged as a result of openness to ideas from sources such as actor-network theory, material sociology, and even physics. Indeed, by drawing on such influences, Orlikowski (2007) emphasized the sociomateriality of ongoing practices which, she argues, has the potential to sensitize researchers to sets of issues that have traditionally not been a focus of attention. After reviewing the organization studies literature, she further argues that the resultant insights are, to a large extent, limiting due to the discipline overlooking "the ways in which organizing is bound up with the material forms and spaces through which humans act and interact." She calls for sociomateriality as a way of providing an alternative conceptualization, which challenges the assumption in the extant organizational literature that organizations, work, and technology should be conceptualized separately (Orlikowski \& Scott 2008). At a macro level, some of the objectives of this development lead to the questioning of received views (Cecez-Kecmanovic et al. 2014) and sensitizing of researchers to a "different set of issues and influences" (Orlikowski 2007), and "to broaden horizons and open up debate rather than to mark off turf or close down avenues of thought" (Orlikowski \& Scott 2013). At a more operational level, the use of the sociomaterial perspective adds to the "palette of concepts in use" (Orlikowski \& Scott 2008) and helps to develop an "alternative toolkit" from existing perspectives (Scott \& Orlikowski 2014).

While drawing on external theories sometimes leads to protracted theoretical discussions and debates, it also has the potential to bring assumptions to the surface and offer new avenues for research. In the project management discipline, as in information systems, material objects are central to the actuality of the underlying tasks. Exploration of this theoretical stream therefore has the potential to reinvigorate the research agenda, and to provide new insights that can only be to the benefit of project management research and practice.

\section{The projectification of the nonprofit sector}

The nonprofit or "third" sector, as it is sometimes called, is a catch-all term for everything that doesn't fit into the "primary" and "secondary" categories of the state and the market. It is characterized by voluntary participation, value-based motivation, and/or independence from more institutionalized power structures (Corry 2010), and is generally viewed as consisting of a broad range of formal, private, nonprofit-distributing, self-governing, and voluntary organizations (Salamon \& Anheier 1992). Like many sectors, it has become increasingly projectified in recent years. In the public and market sectors, projects function as tools to separate certain activities within the organization (Czibere 2014); in the nonprofit sector, the same is true, but there is an added dependence on earmarked funding that drives the way in which work is organized.

Whether it comes from government grants, philanthropic investment, or public donations, an NGO in receipt of funding must organize and report on the basis of income received for projects it has committed to undertake. Ownership of such projects is often vested with the donor, while control (management) rests with the organization that receives the funding. The relationship between the two is based on the ability of the latter to deliver measured results and have impact. It brings the term "project" into daily use in organizational discourse, while leading to a variety of understandings of the formal practices and processes associated with it (Maylor et al. 2006).

As a case in point, the Limerick conference on Delivering Social Good heard how the reality today, for a domestic abuse service set up in the 1970s, is that funders are generally not prepared to look at the organization's action plan in its totality. As a result, the focus 
U T S

e PRES S at operational level is on prioritizing specific projects, seeking funding to implement these, and then moving on to the next projects (Angland 2014). This strategy is based on a combination of capital projects (for example, refurbishing a hall to develop a therapeutic/ educational centre), service delivery projects (including a review of existing services toward working with ex-residents), and organizational development projects (including an initiative to increase funding levels within the organization to enable it to carry out the capital and service delivery projects). As explained by Angland (2014), responsibility for the management of service delivery and organizational development projects was delegated to the manager of the relevant department within the organization, while the management of overarching capital projects rested with the director of services, who also had responsibility for accessing funding for these projects. While needs continue to be identified, and projects to respond to these needs continue to be prioritized, the possibility of implementing these projects is determined primarily by the capacity of the organization to access appropriate funding. For the organization, this availability of funding, rather than the need for the project, very often dictates if and how the project will be undertaken.

The increasing emphasis on projects in organizations right across the nonprofit spectrum has come about in parallel with the emergence of projectification as a phenomenon in other sectors. This is a process of change toward management by projects that is seen as offering flexible, less bureaucratic structures. The concept was introduced over 20 years ago by Christophe Midler, through his research into how industrial firms were implementing fundamental organizational changes in order to increase the efficiency of their product development processes (Midler 1993, 1995). Since then, the boundaries of what constitutes project work have been expanding, and the establishment of programs containing multiple projects, and of portfolios of programs, has become commonplace as a means of managing work (Maylor et al. 2006). And like organizations in the private and public sectors, many NPOs have undergone significant organizational change in this regard in recent years. Projectification and programmification (Maylor et al. 2006) not only influence the operation of the organizations themselves, they also impact on society by forming a project-orientated social order (Czibere 2014). The discursive societal processes through which projects and project-like circumstances are institutionalized (Packendorff \& Lindgren 2014) are in evidence in international development, the delivery of support services, social entrepreneurship, sporting bodies, and a myriad of other nonprofit contexts. Exploring these contexts through case studies and academic articles, as we do in this Special Issue, can help to inform practice across all sectors and illustrate some of the challenges that are now appearing in other project environments.

\section{Learning from project management in the nonprofit sector}

The contributions to this Special Issue offer the potential to not only extend the application of discursive analysis of projects, but to also reverse the dominant flows of scholarly and practice-based knowledge between the business and nonprofit worlds. As we have argued earlier, engagement with external perspectives has the ability to open up new opportunities for research. In the project management discipline, the need to engage in learning between sectors and fields is already recognized (Söderlund 2011; Gauthier \& Ika 2012). So too are the opportunities for practitioners to benefit from examination of issues like participation and control, and from explorations of how real rather than reported value and success can be understood (Lannon et al. 2016).

Project Management Research and Practice, Vol. 3 July-Dec. 2016 
Project management has proved beneficial in circumstances in which complex and extraordinary business tasks are to be managed (Cicmil et al. 2009). Having reached maturity in this context it now needs to consider organizational and societal contexts in which: (i) stakeholder requirements are more complex, ambiguous, multiple, and potentially conflicting; (ii) there is more ambiguity around the aims and objectives, and around what are regarded as successful outcomes to the work; and (iii) projects built upon and extending work undertaken on earlier projects, and projects that lead to further phases of endeavour rather than being ends in and of themselves. There is also a need to widen the value of project management from a control mechanism to one that can take into account the notion of slack, and can accommodate negotiated rather than best practice (Lannon et al. 2016). Such challenges are particularly acute in the nonprofit sector, where the fundamental importance of relationships and agency as a means toward successful outcomes must be balanced with the results-driven imperatives that are increasingly becoming the determinants of success.

The explorations of project management in nonprofit settings in this Special Issue bring these challenges into focus. The lead case study looks at Concern Worldwide (www.concern. net), an organization whose mission is "to help people living in extreme poverty achieve major improvements in their lives which last and spread without ongoing support from Concern" (Concern Worldwide 2015). Its projects focus on areas such as health, education, nutrition, and food security. In 2015, it had 2,660 project staff in the field, responding to 42 emergencies in 24 countries and providing support for 7.6 million people in 28 countries. The article looks at Concern's Realigning Agriculture to Improve Nutrition (RAIN) project in Zambia. In it, Maturri and Pain note that NGO donor requirements tend to militate toward projects that are managed in a siloed way, as these are easier to administer. They also point out that there are lessons to be learned, as well as challenges for managing projects that bring various technical specialists together in a collaborative and coordinated rather than siloed manner. This case illustrates how the use of project management frameworks have the ability to significantly affect the way in which an NPO is structured in response to needs from the external environment. Given the application of a project management perspective, it is not surprising that some of the central issues raised are similar to for-profit organizations: for example, the need for centralized strategic leadership and internally strong leaders, and the need for plans and roles to be jointly developed and agreed among varied stakeholders.

Visser's study of a large-scale collaborative project called The Advocacy Initiative examines a temporary, rather than permanent, organization that sought to reframe relationships with the state, involving many diverse civil society partners and policymakers. Findings centre on building a sense of community among project partners; negotiating devolved ownership of a diverse program of work while maintaining overall coherence; and balancing inward focus while reaching out to engage external stakeholders, through building their confidence and capacity. As a temporary organization it followed the typical project phases (initiating, planning, executing, monitoring and controlling, and closing), providing a structure within which to create a sense of coherence among the diverse stakeholder viewpoints. As in the Concern case study, a project management perspective helped The Advocacy Initiative in dealing with a key challenge, that of overcoming existing silos.

In the third case study in this issue, McKiernan et al. use Trocaire as a case through which to adapt a results based management approach to the nonprofit sector, necessitated over the past decade as a result of pressure to show the effectiveness and results of aid. They consider how results are defined and managed throughout a program cycle. They examine Trócaire's 
journey in adopting results based management, and identify the key success factors and positive results for the organization.

The case studies confirm that project management can provide a valuable way of coping with the complexity of work and external requirements present in a nonprofit environment. However, they also demonstrate that, if used uncritically and if reenacted recursively and unreflectively over time, project management has the potential to result in the functional, instrumental view of the world which was alluded to by Cimcil \& Hodgson (2006). Having achieved the expected first-order effects from project management, practitioners and researchers therefore need to also be sensitive to second-order effects brought about by underlying assumptions that can be both subtle and unacknowledged.

The article by Reddington et al. echoes some of what is found in the preceding case studies, insofar as it is concerned with increasing levels of engagement in a community where there was a variety of stakeholders with multiple, often unstated agendas, and with the application of formal techniques in this environment. The way in which the various techniques were instantiated in practice was unique and showed that formal methods can be applied successfully through high levels of bottom-up rather than top-down participation. While Cimcil \& O'Laocha (2014) argue that instrumental approaches present dilemmas, particularly in relation to agency, the Reddington et al. study illustrates that the techniques can in fact become a means of developing agency among participants, rather than divesting them of it. Rather than suppressing autonomy and leading to marginalization (Hodgson \& Cicmil 2007), the formal methods were used as a way of moving participants from an initial position of "learned helplessness" by increasing their levels of reflexivity and agency.

Lacerda et al. use a case study to examine project portfolio management in an NPO. They provide a comparative analysis of project portfolio management models based on a review of literature, and propose a model to identify how NPOs can best manage a portfolio of projects. Six of their seven dimensions are derived from the project management literature, namely: strategic alignment, definition and allocation of resources, project classification, project evaluation, project selection and prioritization, and portfolio control. For each dimension the authors identify a number of possible elements, and then identify the elements that are relevant for their nonprofit context. The study is a good example of researchers seeking to adapt project management concepts to a new context. As such it provides a developmental trajectory for project management research that involves identifying which dimensions are universally applicable, and which concepts need to be modified and nuanced, in order to make project management more beneficial to a range of contexts and sectors. To draw again on the information systems analogy, the development of enterprise resource planning software balances standard core modules, applicable to any firm, with industry-specific adaptations and modifications enabling more nuanced research and practice. While such customizations make the software more relevant to individual firms, there is a need to critically consider the underlying assumptions and effects of such software at a broader societal level (Walsham 2002). So too with project management, there is a need to not only adopt and adapt methodologies and techniques, but to also question their wider implications more deeply.

Bogacz-Wojtanowska and Jalocha look at projectification in the social economy from this broader perspective, by drawing on 36 case studies of existing social enterprises. Their work provides an insight into how projectification, influenced by European Union policies, changed the landscape for social enterprises in Poland. They argue that projectification is now treated as a natural phenomenon across a wider range of human activity, with the principles and procedures of project thinking increasingly being imposed. They find that this 
U T S

e P R E S S positively influences the development of (European Union funding related) sustainable social enterprises, with projects often seen by members as an instrument through which to start their activities. They also find that the firms they investigated did not submit to projectification pressure or domination from a project approach, again raising the issue of agency in a project environment.

Finally, Ang et al. open up new avenues of inquiry through an investigation of how value constructs are identified in portfolios, using an in-depth case study of two interrelated organizations. In examining the complexity of multiple stakeholder value perspectives, they consider similar issues to those present in some of the other case studies (Matturi and Pain, Visser). However, this article examines historical perspectives on the nature of an underlying concept of value in decision-making in project management contexts. The authors find that value, as described by various stakeholders in nonprofit scenarios, can be categorized under seven different value perspectives. This typology has the potential to change how managers understand what is an underlying concept in project management. The article exemplifies how, as we argued earlier, drawing on concepts and theories from other disciplines has the potential to reduce the reliance on an overarching orthodoxy, sensitizing both academics and practitioners to new phenomena that, over time, can lead to the development of alternative perspectives.

These articles provide a range of examples of NPOs that have adopted project management methodologies, receiving benefits from the structure that imposes, and using the formal methods to overcome rather than reinforce marginalization and a lack of agency. There are also examples of adaption as well as adoption of project management principles. Together the contributions not only seek to develop more nuanced, sector-specific operational models, but also consider wider implications such as the effects of projectification, as well as integrating external concepts in order to reexamine and theorize underlying project management concepts.

\section{Looking forward}

The discipline of project management has enabled organizations to meet the challenge of complexity by rationally managing the coordination of interrelated activities to achieve a defined goal. Projectification, also drawing on the notion of rationality, provides a level of control while offering flexible, less bureaucratic structures. But it also shapes the way people, organizations, and society understand and describe what they do, by imposing ways of working that are constraining as well as enabling. In this editorial, we have argued for both researchers and practitioners to look beyond what is already accepted in the discipline and to suggest possible avenues for future developments. One way of achieving this is to look outside project management research to developments in related domains. We chose information systems since, like project management, it not only has the ability to coordinate complex tasks through a reliance on structural methodologies, but also has the potential to constrain reflexivity and individual action, subordinating them to the requirements of a highly codified way of doing things.

Both domains were similar in their early stages, with research taking an initially positivist perspective, which resulted in the constraint of human action, as well as a marginalization of agency and reflexivity. In the information systems discipline, there was a move from functionalist deterministic claims to a view that gave more priority to human agency, with the meanings and uses of technology being neither fixed nor neutral but open to continual and emergent shaping within particular contexts and cultures: a move with similarities to 
U T S

e PRES S developments in project management. But while it is valuable such a move carries with it the risk, as in the information systems discipline, of emphasising the human and social, with the physical and material aspects of technologies being reduced or ignored. The sociomaterial perspective that was developed in response to this shows the natural development and changes in perspectives within a domain.

In addition to the value of new perspectives in altering dominant paradigms and questioning assumptions, the types of issues raised by recent empirical work that draws on sociomateriality are of relevance to the project management discipline. Indeed one of the first works to address the implications of sociomateriality, and its emphasis on the inextricability and inseparability of the social and the material, looked at how troubled software projects survive and result in working information systems (Wagner et al. 2010). By framing strategies for project survival they shifted the discourse from best practice to negotiated practice. Agency is seen as an enactment rather than what someone has (Leonardi 2013). This was also examined by Venters et al. (2014) in their study of digital coordination, leading them to examine how agencies (both human and non-human) for coordination are temporally embedded, identifying three coordination tensions.

Finally, researchers and educators should take the opportunity to examine how best to apply the techniques, methodologies, and lessons from the nonprofit sector in other contexts. Some work has already been done in the area: for example, Ssegawa \& Muzinda's (2016) case study in which the results-based management approach was used to guide the delivery of a business project in Botswana; or Franks's (2007) work on regeneration projects, which explores the similarities with "ill-structured" international development projects. In selecting papers for this Special Issue, we sought to move this developmental agenda for project management forward. The case studies and papers illustrate how project management principles and methodologies can be applied in varying ways to a relatively new domain, which we argue possesses unique characteristics: the nonprofit sector. They demonstrate the potential for successful application of managerialist and instrumental approaches, in contexts where the "social" is paramount, but they also indicate the need to question prevailing assumptions and to be mindful of the broader societal implications of adopting these approaches.

\section{About the authors}

John Lannon is based at the Centre for Project Management (CPM) in the University of Limerick where he is programme director of the Centre's online MSc in Project and Programme Management. His primary research interest is in the behaviour and needs of organisations and movements that aim to deliver positive social change, with a focus on projects as a form of organising, the use of information communications technologies (ICTs), sharing and re-use of knowledge, stakeholder engagement, accountability and impact assessment. In recent years he has been involved in a number of initiatives with non-governmental organisations, looking at how best to address the challenges they face. Before joining the academic world John worked in the IT sector, first as a software designer and developer and then as a project manager mostly in the telecommunications and enterprise solutions sectors.

John N. Walsh is a lecturer in Information Management in the Kemmy Business School, University of Limerick. He received his PhD from Brunel University for work that examined the effects of social practices on Knowledge Management Repository Re-Use. His research 
U T S

e P R E S S interests focus on the socio-material and organisational effects of knowledge sharing in computer mediated environments.

\section{References}

Angland, J. 2014, 'Project management approach in ADAPT Domestic Abuse Services', paper presented at Delivering Social Good: Managing Projects in the Non-Profit Sector, University of Limerick, Ireland, 20-21 October 2014.

Barley, S.C. 1986, 'Technology as an occasion for structuring: evidence from observations of CT Scanners and the social order of radiology departments', Administrative Science Quarterly, vol. 31, no. 1, pp. 78-108. http://dx.doi.org/10.2307/2392767

Barley, S.R. 1988, 'Technology, power, and the social organization of work', Research in the Sociology of Organizations, vol. 6, pp. 33-80.

Beck, T.E., Lengnick-Hall, C.A. \& Lengnick-Hall, M.L. 2008, 'Solutions out of context: examining the transfer of business concepts to nonprofit organizations', Nonprofit Management and Leadership, vol. 19, no. 2, pp. 153-71. http://dx.doi.org/10.1002/nml.213

Berg, M. 1997, 'Of forms, containers, and the electronic medical record: some tools for a sociology of the formal', Science, Technology, \& Human Values, vol. 22, no. 4, pp. 403-33. http://dx.doi. org/10.1177/016224399702200401

Bijker, W.E., Hughes, T.P. \& Pinch, T. (eds.) 1987, The social construction of technological systems, MIT Press, Cambridge, Ma.

Bijker, W.E. \& Laws, L. (eds.) 1992, Shaping technology, building society: studies in sociotechnical change, MIT Press, Cambridge, Ma.

Button, G. 1993, 'The curious case of the vanishing technology', in G. Button (ed.), Technology in working order: studies in work, interaction, and technology, Routledge, London, pp. 10-28.

Carlos Pinho, J., Paula Rodrigues, A. \& Dibb, S. 2014, 'The role of corporate culture, market orientation and organisational commitment in organisational performance: the case of non-profit organisations', Journal of Management Development, vol. 33, no. 4, pp. 374-98. http://dx.doi.org/10.1108/JMD-03-2013-0036

Cecez-Kecmanovic, D., Galliers, R.D., Henfridsson, O., Newell, S. \& Vidgen, R. 2014, 'The sociomateriality of information systems: current status, future directions', MIS Quarterly, vol. 38, no. 3, pp. 809-30.

Ciborra, C. \& Lengel, G.F. 1994, 'Formative contexts and ICT: understanding the dynamics of innovation in organizations', Accounting, Management and Information Technology, vol. 4, no. 2, pp. 61-86. http://dx.doi.org/10.1016/0959-8022(94)90005-1

Cicmil, S. \& Hodgson, D. 2006, 'Are projects real? The PMBOK and the legitimation of project management knowledge', in S. Cicmil \& D. Hodgson (eds.), Making Projects Critical, Palgrave Macmillan, New York.

Cicmil, S., Williams, T., Thomas, J. \& Hodgson, D. 2006, 'Rethinking project management: researching the actuality of projects', International Journal of Project Management, vol. 24, no. 8, pp. 675-86. http:// dx.doi.org/10.1016/j.ijproman.2006.08.006

Cicmil, S., Hodgson, D., Lindgren, M. \& Packendorff, J. 2009, 'Project management behind the façade', Ephemera: Theory \& Politics in Organization, vol. 9, no. 2, pp. 78-92. 
Cicmil, S. \& O'Laocha, E. 2014, 'Responsible management of projects in the context of international development: a critical overview of governance, leadership and power', paper presented at Delivering Social Good: Managing Projects in the Non-Profit Sector, University of Limerick, Ireland, 20-21 October 2014.

Concern Worldwide 2015, Concern Worldwide: Annual report and accounts 2015, https://www.concern.net/ sites/default/files/html/reports/2015/contents.html.

Corry, O. 2010, 'Defining and theorizing the third sector', in R. Taylor (ed.), Third sector research, Springer, New York, pp. 11-20. http://dx.doi.org/10.1007/978-1-4419-5707-8 2

Curtis, D. \& Poon, Y. 2009, 'Why a managerialist pursuit will not necessarily lead to achievement of MDGs', Development in Practice, vol. 19, no. 7, pp. 837-48. http://dx.doi. org/10.1080/09614520903122139

Czibere, I. 2014, 'Projects' social effects: the project orientated society', Metszetek, vol. 3, no. 4, pp. 66-77.

Diallo, A. \& Thuillier, D. 2005, ‘The success of international development projects, trust and communication: an African perspective', International Journal of Project Management, vol. 23, no. 3, pp. 237-52.

Drucker, P.F. 1990, Managing the non-profit organization: practices and principles, New York, NY: Taylor \& Francis.

Falgari, M., Golini, R., Kalchschmidt, M. \& Landoni, P. 2013, 'Managing international development projects: evidences from an international survey', Atti della XXIV Riunione scientifica annuale Associazione Italiana di Ingegneria Gestionale (RSA AiIG 2013), 17-18 Ottobre 2013, Milano.

Gauthier, J.B. \& Ika, L.A. 2012, 'Foundations of project management research: an explicit and six-facet ontological framework', Project Management Journal, vol. 43, no. 5, pp. 5-23. http://dx.doi.org/10.1002/ pmj.21288

Giddens, A. 1984, The constitution of society, Polity Press, Cambridge.

Golini, R., Kalchschmidt, M. \& Landoni, P. 2015, 'Adoption of project management practices: the impact on international development projects of non-governmental organizations', International Journal of Project Management, vol. 33, no. 3, pp. 650-63. http://dx.doi.org/10.1016/j.ijproman.2014.09.006

Golini, R. \& Landoni, P. 2014, 'International development projects by non-governmental organizations: an evaluation of the need for specific project management and appraisal tools', Impact Assessment and Project Appraisal, vol. 32, no. 2, pp. 121-35. http://dx.doi.org/10.1080/14615517.2014.894088

Harvey, E. 1968, 'Technology and the structure of organizations', American Sociological Review, vol.33, no. 2, pp. 247-59. http://dx.doi.org/10.2307/2092391

Helgadóttir, H. 2008, 'The ethical dimension of project management', International Journal of Project Management, vol. 26, no. 7, pp. 743-48. http://dx.doi.org/10.1016/j.ijproman.2007.11.002

Hirschheim, R. 1985, Office automation: a social and organizational perspective, John Wiley \& Sons, New York.

Hodgson, D. \& Cicmil, S. 2007, 'The other side of projects: the case for critical project studies', International Journal of Managing Projects in Business, vol. 1, no. 1, pp. 142-52.

Ika, L.A. 2012, 'Project management for development in Africa: why projects are failing and what can be done about it', Project Management Journal, vol. 43, no. 4, pp. 27-41. http://dx.doi.org/10.1002/ pmj. 21281

Ika, L.A., Diallo, A. \& Thuillier, D. 2010, 'Project management in the international development industry: the project coordinator's perspective', International Journal of Managing Projects in Business, vol. 3, no. 1, pp. 61-93. http://dx.doi.org/10.1108/17538371011014035 
U T S

e PRES S
Ika, L.A. and Hodgson, D. 2014, 'Learning from international development projects: blending critical project studies and critical development studies', International Journal of Project Management, vol. 32, no. 7, pp. 1182-96. http://dx.doi.org/10.1016/j.ijproman.2014.01.004

Khang, D.B. \& Moe, T.L. 2008, 'Success criteria and factors for international development projects: a life-cycle-based framework', Project Management Journal, vol. 39, no. 1, pp. 72-84. http://dx.doi. org/10.1002/pmj.20034

Kling, R. 1987, 'Defining the boundaries of computing across complex organizations', in R. Boland \& R. Hirscheim (eds.), Critical issues in information systems, John Wiley \& Sons, New York, pp. 307-62.

Kling, R. 1991, 'Computerization and social transformation', Science, Technology, E Human Values, vol. 16, no. 3, pp. 342-67.

Krause, M. 2014, The good project: humanitarian relief NGOs and the fragmentation of reason, University of Chicago Press. http://dx.doi.org/10.7208/chicago/9780226131535.001.0001

Lannon, J., Aherne, D. \& Burke, C. 2016, 'Guest editorial: project management in international development', International Journal of Managing Projects in Business, vol. 9, no. 3.

Leonardi, P.M. 2013, 'Theoretical foundations for the study of sociomateriality', Information and Organization, vol. 23, no. 2, pp. 59-76. http://dx.doi.org/10.1016/j.infoandorg.2013.02.002

Lindgren, M. \& Packendorf, J. 2006, 'Projects in prisons', in W.D. Hodgson \& S. Cicmil (eds.), Making projects critical, Palgrave Macmillan, New York, pp 111-131.

Markus, M.L. \& Robey, D. 1988, 'Information technology and organizational change: causal structure in theory and research', Management Science, vol. 34, no. 5, pp. 583-98. http://dx.doi.org/10.1287/ mnsc. 34.5 .583

Maier, F., Meyer, M. \& Steinbereithner, M. 2016, 'Nonprofit organizations becoming business-like a systematic review', Nonprofit and Voluntary Sector Quarterly, vol. 45, no. 1, pp. 64-86. http://dx.doi. org/10.1177/0899764014561796

Maylor, H., Brady, T., Cooke-Davies, T. \& Hodgson, D. 2006, 'From projectification to programmification', International Journal of Project Management, vol. 24, no. 8, pp. 663-74. http://dx.doi. org/10.1016/j.ijproman.2006.09.014

Midler, C. 1995, "Projectification" of the firm: the Renault case', Scandinavian Journal of Management, vol. 11, no. 4, pp. 363-75. http://dx.doi.org/10.1016/0956-5221(95)00035-T

Myers, J. \& Sacks, R. 2003, 'Tools, techniques and tightropes: the art of walking and talking private sector management in non-profit organisations, is it just a question of balance?', Financial Accountability \& Management, vol. 19, no. 3, pp. 287-306. http://dx.doi.org/10.1111/1468-0408.00175

Orlikowki, W.J. \& Iacono, C.S. 2001, 'Desperately seeking the "IT" in IT research: a call to theorizing the IT artefact', Information Systems Journal, vol. 12, no. 2, pp. 121-34.

Orlikowski, W.J. 2000, 'Using technology and constituting structures: a practice lens for studying technology in organizations', Organization Science, vol. 11, no. 4, pp. 404-28. http://dx.doi.org/10.1287/ orsc.11.4.404.14600

Orlikowski, W.J. 2007, 'Sociomaterial practices: exploring technology at work', Organization Studies, vol. 29, no. 9, pp. 1435-48. http://dx.doi.org/10.1177/0170840607081138

Orlikowski, W.J. 2010, 'The sociomateriality of organisational life: considering technology in management research', Cambridge Journal of Economics, vol. 34, pp. 125-41. http://dx.doi.org/10.1093/cje/bep058 
U T S

e PRES S

Orlikowski, W.J. \& Robey, D. 1991, 'Information technology and the structuring of organizations', Information Systems Research, vol. 2, no. 2, pp. 143-67. http://dx.doi.org/10.1287/isre.2.2.143

Orlikowski, W.J. \& Scott, S.V.2008, 'Sociomateriality: challenging the separation of technology, work and organization', The Academy of Management Annals, vol. 2, no. 1, pp. 433-74. http://dx.doi. org/10.1080/19416520802211644

Packendorff, J. \& Lindgren, M. 2014, 'Projectification and its consequences: narrow and broad conceptualisations', South African Journal of Economic and Management Sciences, vol. 17, no. 1, pp. 7-21. http://dx.doi.org/10.1002/pmj.21418

Packendorff, J., Crevani, L. \& Lindgren, M. 2014, 'Project leadership in becoming: a process study of an organizational change project', Project Management Journal, vol. 17, no. 17, pp. 7-21.

Pinch, T.J. \& Bijker, W.E. 1984, 'The social construction of facts and artefacts: or how the sociology of science and the sociology of technology might benefit each other', Social Studies of Science, vol. 14, no. 3, pp. 399-441.

Ryan, W.P. (2002), 'The new landscape for nonprofits,' in V. Futter, J.A.Cion, and G.W. Overton (eds.), Nonprofit governance and management, Chicago, IL: American Bar Association, pp. 13-28.

Salamon, L.M. \& Anheier, H.K. 1992, 'In search of the non-profit sector I: the question of definitions', Voluntas: International Journal of Voluntary and Nonprofit Organizations, vol. 3, no. 2, pp. 125-51. http:// dx.doi.org/10.1007/BF01397770

Scott, S.V. \& Orlikowski, W.J. 2013, 'Sociomateriality - taking the wrong turn? A response to Mutch', Information and Organization, vol. 23, no. 2, pp. 77-80. http://dx.doi.org/10.1016/j. infoandorg.2013.02.003

Scott, S.V. \& Orlikowski, W.J. 2014, 'Entanglements in practice: performing anonymity through social media', MIS Quarterly, vol. 38, no. 3, pp. 873-93.

Söderlund, J. 2011, 'Pluralism in project management: navigating the crossroads of specialization and fragmentation', International Journal of Management Revierws, vol. 13, no. 2, pp. 153-76. http://dx.doi. org/10.1111/j.1468-2370.2010.00290.x

Ssegawa, J.K. \& Muzinda, M. 2016, 'Using RBM approach in managing projects beyond the development sector', International Journal of Managing Projects in Business, vol. 9, no. 2, pp. 337-63. http://dx.doi.org/10.1108/IJMPB-09-2015-0084

Suchman, L.A. 1994, 'Do categories have poitics?', Computer Supported Cooperative Work, vol. 2, no. 3, pp. 177-90. http://dx.doi.org/10.1007/BF00749015

Tucker, B.P. \& Parker, L.D. 2013, 'Managerial control and strategy in nonprofit organizations: doing the right things for the wrong reasons?', Nonprofit Management and Leadership, vol. 24, no. 1, pp. 87-107. http://dx.doi.org/10.1002/nml.21082

Venters, W., Oborn, E. \& Barrett, M. 2014, 'A trichordial temporal approach to digital coordination: the sociomaterial mangling of the CERN grid', MIS Quarterly, vol. 38, no. 3, pp. 927-49.

Wagner, E.L., Newell, S. \& Piccoli, G. 2010, 'Understanding project survival in an ES environment: a sociomaterial practice perspective', Journal of the Association for Information Systems, vol. 11, no. 5, pp. 276-97.

Woodward, J. 1958, Management and technology, HMSO, London.

Zuboff, S. 1988, In the age of the smart machine: the future of work and power, Basic Books, New York. 